\title{
Antarctobacter heliothermus gen. nov., sp. nov., a budding bacterium from hypersaline and heliothermal Ekho Lake
}

\author{
Matthias Labrenz, ${ }^{1}$ M. David Collins, ${ }^{2}$ Paul A. Lawson, ${ }^{2}$ Brian J. Tindall, ${ }^{3}$ \\ Gesche Braker ${ }^{1}$ and Peter Hirsch
}

\begin{abstract}
Author for correspondence: Peter Hirsch. Tel: +49 4318804340 . Fax : +49 4318802194.
e-mail: phirsch@ifam.uni-kiel.de
\end{abstract}

\footnotetext{
1 Institut für Allgemeine Mikrobiologie, Universität Kiel, D-24118 Kiel, Germany

2 Department of Microbiology, BBSRC Institute of Food Research, Reading Laboratory, Reading RG6 6BZ, UK

${ }^{3}$ DSMZ - Deutsche Sammlung von Mikroorganismen und Zellkulturen, D-38124 Braunschweig, Germany
}

\begin{abstract}
Four Gram-negative, aerobic, pointed and budding bacteria were isolated from various depths of the hypersaline, heliothermal and meromictic Ekho Lake (Vestfold Hills, East Antarctica). The cells contained storage granules and formed rosettes. Daughter cells may be motile. Growth required sodium ions. Nitrate was reduced to nitrite, and dissimilatory reduction of nitrite was possible. DNase and gelatinase were produced. Glutamate was metabolized with and without an additional source of combined nitrogen. The most abundant fatty acid was $C_{18: 1}$; other fatty acids present in lower concentrations were $\mathrm{C}_{12: 1} 3-\mathrm{OH}, \mathrm{C}_{16: 1,}, \mathrm{C}_{16: 0}, \mathrm{C}_{18: 0}$ and $\mathrm{C}_{19: 0}$ cyc. The main polar lipids were phosphatidylglycerol and phosphatidylcholine. The DNA base composition was 62.3-62.8 mol\% G+C. 16S rDNA sequence comparisons showed the isolates to be phylogenetically related to the genera Sagittula and Roseobacter. Morphological, physiological and genotypic differences to these and distinct characteristics supported the description of a new genus and a new species, Antarctobacter heliothermus gen. nov., sp. nov. The type strain is EL-219 ${ }^{\top}$ (= DSM 11445').
\end{abstract}

Keywords: Antarctobacter gen. nov., Antarctobacter heliothermus sp. nov., $\alpha$-Proteobacteria, Antarctica, hypersaline lakes

\section{INTRODUCTION}

The ice-free area of the Vestfold Hills (East Antarctica) abounds with lakes and ponds of various sizes. Several of these lakes originated from fjords and, at one time, were open to the ocean. Thus, seawater determined their initial salt composition and concentration and, most likely, also the composition of their microbial communities. As the land rose about 5000-6000 years ago the fjords lost their connections to the ocean and became lakes. One such lake is Ekho Lake, which has since lost approximately $10 \mathrm{~m}$ of its water column due to evaporation; this and a minor influx of snow melt water have resulted in increased salinity. In addition, a vertical gradient of salinity exists; this was explained by Ferris 't al. (9) as follows. The annual freezing of the lake water surface forms several metres of ice

Abbreviations: ASW, artificial seawater; FAME, fatty acid methyl ester. The EMBL accession numbers for the 16S rRNA sequences of strain EL-219 ${ }^{\top}$ and strain EL-172, another representative out of Ekho Lake, are Y11552 and Y11551, respectively. cover. In this process, much salt is excluded as brine, which sinks downwards towards lower strata along the shore line. Consequently, zones of stepwise increasing salinity with depth were formed. In Ekho Lake, a summer salinity of $2-10 \%$ was measured between 0 and $1 \mathrm{~m}$ depth, whereas the salinity was $180 \%$ at the bottom depth of $42 \mathrm{~m}$. At interfaces between zones of increasing depth, the salt concentration increased suddenly to the next higher level. Close to, and below, these interfaces temperature increases were measured. Thus, these interfaces appeared to act as one-way mirrors, allowing sun radiation to penetrate into the lower layers but preventing its escape due to downward deflection. The strata below such interfaces were significantly warmer than the upper ones: the lake is considered to be heliothermally heated. A similar situation has been described for Solar Lake (Sinai) (19, 21). Another consequence of separated water bodies with high salinity is meromixis. Wind energy does not turn over the lower strata in the summer, and during winter a turnover is prevented by a thick ice cover. The temperature of the lower layers of Ekho Lake remains 
at about $+13{ }^{\circ} \mathrm{C}$ in winter. During the austral summer, intermediate strata reached as high as $+19^{\circ} \mathrm{C}(\mathrm{P}$. Hirsch \& J. Siebert, unpublished). Because of these differences of environmental parameters at increasing depths, microbial communities of this hypersaline, heliothermal and meromictic Ekho Lake were studied.

To date, only a few bacterial species or genera have been isolated from similar Antarctic lakes; some of these were new. Nearby Organic Lake contained Halomonas subglaciescola $(6,10), 16$ strains of the Flavobacterium-Cytophaga-Flexibacter group (4), Flavobacterium gondwanense and Flavobacterium salegens (5). Deep Lake contained the new taxon Halorubrum ('Halobacterium') lacusprofundi (15). Other new bacteria came from Ace Lake: Carnobacterium funditum and Carnobacterium alterfunditum (12), a spiral-shaped, psychrophilic and fermentative bacterium (13), a methanogenic and methylotrophic archaeon, Methanococcoides burtonii (14), and a psychrophilic spirochaete lacking a cell wall (11).

The presence of two Halomonas and two Flavobacterium species in various hypersaline lakes of the Vestfold Hills was studied by James et al. (24), who employed immunofluorescence of specific antibodies. These four serogroups were found during summer in those lakes which exceeded $61 \%$ of total salts. The two Halomonas spp. made up $40 \%$ of the total bacterial numbers, but $F$. gondwanense contributed only $10 \%$ of these numbers in Organic and Ekho Lake. The microbial communities of Ekho Lake remained largely unknown.

The morphological diversity, total bacterial numbers and c.f.u. in Ekho Lake were recently studied by P. Hirsch, J. Siebert \& H. R. Burton (unpublished). These authors observed 135 prokaryotic morphotypes as well as 52 eukaryotic morphotypes. Such an unexpectedly high morphological diversity in Ekho Lake prompted us to isolate some 250 bacterial pure cultures from Ekho Lake, and a high taxonomic (genetic) diversity was expected. Additionally, the isolation of the major photosynthetic primary producer of Ekho Lake resulted in the description of a new green praseophyte, 'Tetraselmis antarctica' (20). This publication describes four Ekho Lake bacterial isolates which represent a new genus and species.

\section{METHODS}

Water sampling, enrichment conditions and isolations. Water samples were taken aseptically at each metre of the depth profile using a Kammerer sampler at the 42-m-deep centre of Ekho Lake (20). Samples were stored on ice until used for the inoculation of enrichments or plates after return to the Davis Station laboratory (Vestfold Hills). Characteristics of these water samples are shown in Table 1. Enrichments were set up in three different ways. (I) A $5 \mathrm{ml}$ Ekho Lake water sample was inoculated into $10 \mathrm{ml}$ sterile medium ' $398^{\prime}$ ' and incubated for 4 weeks at $15^{\circ} \mathrm{C}$ under dim light $\left(4 \cdot 1 \mu \mathrm{mol}\right.$ photons $\left.\mathrm{m}^{-2} \mathrm{~s}^{-1}\right)$. Medium ' $398^{\prime}$ ' had the following composition: Hutner's Basal Salts (HBM; 2), $20 \mathrm{ml}$; Bacto yeast extract (Difco), $1.0 \mathrm{~g}$; disodium D,L- malate, $1.0 \mathrm{~g}$; Ekho Lake water (salinity $98 \%$ ), $980 \mathrm{ml}$; final $\mathrm{pH}$ after autoclaving 8.6. (II) Ekho Lake water samples $(50 \mathrm{ml})$ were amended with $1 \mathrm{ml}$ of a filter-sterilized solution of $12.5 \mathrm{mg}$ Bacto yeast extract in lake water and incubated at $15^{\circ} \mathrm{C}$ and at $4 \cdot 1 \mu \mathrm{mol}$ photons $\mathrm{m}^{-2} \mathrm{~s}^{-1}$. (III) Ekho Lake water samples $(0.5 \mathrm{ml})$ were spread directly on agar plates of medium PYGV (41) which had been prepared with Ekho Lake water of $10 \%$ salinity. Incubation was at $15^{\circ} \mathrm{C}$ and in the dark. Pure cultures were isolated by several dilution transfers on the corresponding agar media; they were kept as serial transfers on agar slants, lyophilized or deep-frozen at $-72^{\circ} \mathrm{C}$

Bacterial strains. Type strains used for comparisons were of the following species: Roseobacter denitrificans (DSM $7001^{\mathrm{T}}$ ), Roseobacter litoralis (DSM 6996 ${ }^{\mathrm{T}}$ ) and Roseobacter algicola (DSM $\left.10251^{\mathrm{T}}\right)$.

Media and culture conditions. Medium PYGV contained $\left(\mathrm{l}^{-1}\right): 0.25 \mathrm{~g}$ each of Bacto peptone, Bacto yeast extract and glucose as well as $20 \mathrm{ml}$ HBM and $10 \mathrm{ml}$ Vitamin Solution no. 6(45). Solid media contained $1.8 \%(\mathrm{w} / \mathrm{v})$ Bacteriological agar (Gibco). Where needed, liquid and solid media were prepared with $25 \%$ (v/v) artificial seawater (ASW; 28) (strains EL-219 , EL-185, EL-165, R. algicola, $R$. denitrificans and $R$. litoralis) or, in case of EL-54, with $40 \%$ ASW. Before autoclaving, medium PYGV containing ASW was adjusted to a $\mathrm{pH}$ of $8 \cdot 5$; the final $\mathrm{pH}$ after autoclaving was 7.2. R2A agar (Difco) was prepared with the corresponding concentration of ASW and was employed to culture the strains for BIOLOG tests. Bacterial cultures for identification tests were incubated at $20^{\circ} \mathrm{C}$; the anaerobic cultivation of isolates (at 4-21.5 $\mu \mathrm{mol}$ photons $\mathrm{m}^{-2} \mathrm{~s}^{-1}$ ) occurred at $16^{\circ} \mathrm{C}$. Biomass for chemotaxonomic studies was grown in liquid PYGV + ASW at $20^{\circ} \mathrm{C}$ that was bubbled with filtersterilized air and harvested in the late-exponential phase after $4-8 \mathrm{~d}$.

Microscopy. Cellular morphology was examined by phasecontrast light microscopy of exponential phase broth cultures employing $2 \%$ water-agar-coated slides (31). For transmission electron microscopy, cells were washed with $0.5 \mathrm{M}$ ammonium acetate, negatively stained with $1 \%(\mathrm{w} / \mathrm{v})$ phosphotungstic acid and observed with a Philips EM 300 electron microscope at $80 \mathrm{kV}$.

Physiological and biochemical characterization. All physiological tests were performed at $20^{\circ} \mathrm{C}$. Gram-staining occurred with $24 \mathrm{~h}$ cultures (39). Catalase production was detected with $5 \% \mathrm{H}_{2} \mathrm{O}_{2}$. Peroxidase and cy tochrome oxidase activity was tested as described previously $(7,26)$. DNA hydrolysis was indicated by clear zones around colonies on Bacto DNase Test agar (Difco) + ASW. Amylase and the relation to oxygen were studied as described previously (40). Cellulase was tested with bacterial suspensions with 4methylumbelliferyl $\beta$-D-glucoside (Sigma) under UV light $(366 \mathrm{~nm})$. Motility was examined in hanging-drop preparations. Additionally, EL-219 ${ }^{\mathrm{T}}$ was examined for the presence of flagella by electron microscopy after 1, 2, 3, 4 and $8 \mathrm{~d}$ incubation in broth. The ability to grow under various physical and chemical conditions was investigated in liquid media and evaluated by determining the protein content (1) of triplicate suspensions: osmotolerance in PYGV prepared with 0, 10, 20-100, 130 and 150\% ASW was determined after $14 \mathrm{~d}$ incubation. The concentration of $150 \%$ ASW was achieved by adding $\mathrm{NaCl}$ to $130 \%$ ASW. $\mathrm{NaCl}$ tolerance was determined in PYGV prepared with 0 , $10-40,60,80,100,130$ and $150 \% \mathrm{NaCl}$ after $14 \mathrm{~d}$ incubation. The ability to grow at $\mathrm{pH} 5 \cdot 3,5 \cdot 9,6 \cdot 2,6 \cdot 9,7 \cdot 8,8 \cdot 3$ 
Table 1. Characteristics of the original 1989/90 Ekho Lake samples from which the isolates were obtained, and enrichment conditions

\begin{tabular}{|cccccc|}
\hline $\begin{array}{l}\text { Depth } \\
(\mathbf{m})\end{array}$ & $\begin{array}{c}\text { Salinity } \\
(\%)\end{array}$ & $\begin{array}{c}\text { Temp. } \\
\left({ }^{\circ} \mathrm{C}\right)\end{array}$ & $\mathbf{p H}$ & Isolate & $\begin{array}{c}\text { Enrichment } \\
\text { method }^{*}\end{array}$ \\
\hline 5 & 60 & $+12 \cdot 9$ & $8 \cdot 3$ & EL-185 & I \\
7 & 62 & $+12 \cdot 9$ & $8 \cdot 2$ & EL-2197 & II \\
14 & 75 & $+16 \cdot 0$ & $8 \cdot 0$ & EL-54 & III \\
16 & 76 & $+16 \cdot 4$ & $7 \cdot 8$ & EL-165 & II \\
\hline
\end{tabular}

* See Methods.

and $9 \cdot 0$ and at temperatures of $3 \cdot 0,8 \cdot 5,16 \cdot 0,20 \cdot 0,26 \cdot 0,33 \cdot 5$ and $43.5{ }^{\circ} \mathrm{C}$ was also tested. Requirement(s) for the following vitamins was tested in six combinations, each lacking one vitamin of Vitamin Solution no. 6: biotin, thiamin hydrochloride, nicotinic acid, sodium pantothenate or vitamin $\mathrm{B}_{12}$. For these experiments casein hydrolysate (vitamin-free; Merck) was used instead of Bacto peptone and Bacto yeast extract. Triplicate results were recorded after three serial transfers in the corresponding test media. Requirements for $\mathrm{Na}^{+}, \mathrm{K}, \mathrm{Mg}^{2+}, \mathrm{Ca}^{2+}, \mathrm{Cl}^{-}$or $\mathrm{SO}_{4}^{2-}$ were studied in $\mathrm{PYGV}+$ ASW, where $\mathrm{Na}^{+}$was exchanged with $\mathrm{K}^{+}, \mathrm{Mg}^{2+}$ with $\mathrm{Ca}^{2+}$, $\mathrm{Cl}^{-}$with $\mathrm{SO}_{4}^{2-}$ and vice versa. Identical growth response indicated independence of these cations or anions. Susceptibility to antibiotics was determined with bioDiscs (bioMérieux) and the results were recorded after $4 \mathrm{~d}$. The aerobic reduction of nitrate was tested after $14 \mathrm{~d}$; the anaerobic reduction of nitrate to nitrite or molecular nitrogen was examined after 3 weeks incubation. In both cases, PYGV + ASW which contained $5 \mathrm{mM} \mathrm{NaNO}$, was employed. Anaerobic growth was examined in modified PYGV + ASW, which contained $\left(\mathrm{I}^{-1}\right) 0 \cdot 1 \mathrm{~g}$ glucose, $0 \cdot 1 \mathrm{~g}$ acetate, $0.1 \mathrm{~g}$ glutamate and $0.5 \mathrm{~g}$ Tris. The medium was saturated with $\mathrm{N}_{2}$ for $20 \mathrm{~min}$, and $20 \mathrm{ml}$ was distributed to $100 \mathrm{ml}$ type-III serum bottles. For photolithoautotrophic or photoorganotrophic growth tests, the cultures were incubated under an atmosphere of $\mathrm{H}_{2} / \mathrm{CO}_{2}(80: 20 ; 0.9$ bar $)$ and at light intensities of 4-21.5 $\mu \mathrm{mol}$ photons $\mathrm{m}^{-2} \mathrm{~s}^{-1}$. Production of poly- $\beta$-hydroxybutyrate was determined in PYGV + ASW which was modified to contain $\left(1^{-1}\right) 20 \mathrm{ml}$ HBM, $10 \mathrm{ml}$ Vitamin Solution no. 6, $0.1 \mathrm{~g}$ Bacto yeast extract and $2.0 \mathrm{~g}$ succinate as previously described (40). Methyl red and Voges-Proskauer tests were performed in PYGV + ASW containing $0.2 \%(\mathrm{w} / \mathrm{v})$ Bacto peptone and $0.2 \%(\mathrm{w} / \mathrm{v})$ glucose. $\mathrm{H}_{2} \mathrm{~S}$ and indole production was tested with the sulfide indole motility medium (Merck) + ASW. Indole was detected with $1 \mathrm{ml}$ Kovács' reagent.

To study the aerobic dissimilation of 95 carbon sources with the BIOLOG system, the Microlog software, a Tandon computer and a microplate photometer (Molecular Devices) were used (Biolog). Suspensions were obtained from growth on R2A agar prepared with the individually required concentration of ASW after $34 \mathrm{~d}$ at $20^{\circ} \mathrm{C}$. The cells were suspended in the necessary ASW to a transmission of $53-59 \%$ and inoculated into microplate wells. Test evaluation was performed after 4,24 and $48 \mathrm{~h}$. Additionally, carbon source utilization was studied in a minimal medium containing $\left(\mathrm{l}^{-1}\right)$ : HBM, $20 \mathrm{ml}$; Vitamin Solution no. 6, $10 \mathrm{ml}$; Bacto yeast extract, $0.02 \mathrm{~g}$; and $\mathrm{NH}_{4} \mathrm{NO}_{3}, 0.25 \mathrm{~g}$. The following carbon sources were tested at $0.2 \%(\mathrm{w} / \mathrm{v})$ : acetate, pyruvate, malate, citrate, succinate, butyrate, glutamate, $\alpha$ -
D-glucose, methanol and methanesulfonic acid. Degradation of the following substrates was tested with the basal medium PYV + ASW (i.e. lacking glucose): $0 \cdot 2 \%(\mathrm{w} / \mathrm{v})$ starch, $0.4 \%$ gelatin, $1 \%$ Tween 80 or $0.75 \%$ alginate. Production of bacteriochlorophyll $a$ was tested with suspensions of cells grown in PYGV + ASW and analysed as described previously (38). Methanolic extracts were examined with a Beckman DU-600 spectrophotometer and by TLC (27).

Chemotaxonomy. Analysis of fatty acid methyl esters (FAMEs) was performed on $20 \mathrm{mg}$ freeze-dried cells employing methods which allowed selective hydrolysis of esterand amide-linked fatty acids. FAMEs were analysed by GC (GC-14A; Shimadzu) using a $0.2 \mathrm{~mm} \times 25 \mathrm{~m}$ non-polar capillary column and flame-ionization detector. The chromatography conditions were: injector and detector port temperature $300{ }^{\circ} \mathrm{C}$, inlet pressure $80 \mathrm{kPa}$, split ratio $50: 1$, injection volume $1 \mu \mathrm{l}$ and a temperature program of 130 $310^{\circ} \mathrm{C}$ at a rate of $4^{\circ} \mathrm{C} \mathrm{min}^{-1}$. Hydrogen was the carrier gas. The fatty acids were identified by converting retention times to equivalent chain-length data (35). Saturated $C_{10}-C_{30}$ FAMEs were used as standards. Respiratory lipoquinones and polar lipids were extracted and analysed from $100 \mathrm{mg}$ freeze-dried cells using the two-stage method as previously described $(43,44)$. Purified cell wall preparations were obtained by the methods of Schleifer \& Kandler (36). Amino acids and peptides of cell wall hydrolysates were analysed by two-dimensional ascending TLC on cellulose plates using solvent systems described previously (36). Diamino acids were recognized by one-dimensional TLC on cellulose using a solvent system of Rhuland et al. (32).

Determination of DNA base composition. DNA $\mathrm{G}+\mathrm{C}$ contents were analysed using HPLC (29). The HPLC apparatus (Pharmacia-LKB) was equipped with a Spherisorb ODS II $\mathrm{C}_{18}$ column $(5 \mu \mathrm{m} ; 4 \times 250 \mathrm{~mm}$; Bischoff, Leonberg). Escherichia coli Strain B Type VIII-DNA (Sigma) and lambda phage DNA from E. coli host strain GM 119 (Sigma) were used as standards.

DNA-DNA hybridization. Dot-blot hybridization experiments were carried out with the DIG DNA Labeling and Detection kit from Boehringer Mannheim following the manufacturer's instructions. Gene probes were made from EL-219 $19^{\mathrm{T}}$ and hybridized against chromosomal DNA of EL185 , EL-165, EL-54 and $R$. denitrificans. The stringency of 70 and $75 \%$ was calculated according to Sambrook et al. (34).

$16 S$ rRNA sequence determination and analysis of sequence data. 16S rRNA gene fragments were generated by PCR as previously described (23). A large fragment of the 16S rRNA gene was amplified from DNA using universal primers $\mathrm{pA}$ (positions 8-28, E. coli numbering) and $\mathrm{pH}^{*}$ (1542-1522). The amplified product was purified by using a QIAquick PCR Purification kit (Qiagen) and sequenced directly using primers to conserved regions of the rRNA. Sequencing was performed using a PRISM Taq DyeDeoxy Terminator Cycle Sequencing kit (Applied Biosystems) and an automatic DNA sequencer (model 373A; Applied Biosystems). To establish the closest relatives of the four Ekho Lake strains, preliminary searches in the EMBL database were performed with the program FASTA (30). Sequences closely related to those of the Ekho Lake strains were retrieved from the EMBL database and aligned with the newly determined sequences using the program PILEUP (3). The rRNA alignment was corrected manually and approximately 100 bases at the $5^{\prime}$ end of the molecule were omitted from further analysis because of alignment uncertainties due to the highly 
variable region V1. Percentage sequence similarities were calculated and corrected for substitution rates by using Jukes \& Cantor parameters (25). A phylogenetic tree was constructed according to the neighbour-joining method (33) with the program NEIGHBOR. For this analysis, the following additional taxa, listed by genera and accession number, were included: Rhodomicrobium vannielii (M34127), 'Methylosulfonomonas methylovora' (U62893), Rhodobium marinum (D30790), Rhodobium orientis (D30792), Rhodospirillum salexigens (M59070), Rhodovulum euryhalinum (D13479), Rhodovulum sulfidophilum (U55277), Rhodovulum adriaticum (D16418), Rhodobacter blasticus (D16429), Rhodobacter capsulatus (D16428), Rhodobacter sphaeroides (D16425), Rhodobacter veldkampii (D16421), Rhodospirillum rubrum (D30778), Rhodospirillum photometricum (D30777), Rhodospirillum fulvum (D14433), Rhodospirillum molischianum (M59067), Rhodospirillum salinarum (M59069), Rhodospirillum sodomense (M59072), Rhodopila globiformis (M59066), Rhodoplanes roseus (D25313), Blastochloris viridis (D25314), Rhodopseudomonas palustris (D25312) and Rhodopseudomonas acidophila (M34128). The stability of the groupings was estimated by bootstrap analysis (500 replications) using the programs SEQBOOT, DNADIST, NEIGHBOR and CONSENSE of the PHYLIP package (8).

\section{RESULTS}

\section{Isolation of bacteria, morphology and motility}

Three different enrichment procedures yielded four pure cultures with similar morphology; they were obtained from 5, 7, 14 and $16 \mathrm{~m}$ Ekho Lake samples (Table 1). These isolates are referred to as EL-219 EL-54, EL-165 and EL-185. They all were Gramnegative rods with one or both cell poles narrower, and of variable length (Fig. 1a, b). Cells had a tendency to form rosettes (Table 2; Fig. 1c). Cell growth appeared to be monopolar since one cell end was usually narrower and shorter, possibly indicating a budding process (18). In such cases, the 'daughter cell' was often positioned at an angle to the 'mother cell' (Fig. 1c). All four isolates contained electron-transparent poly- $\beta$-hydroxybutyrate granules. Their cell sizes were very similar; a peculiar characteristic of laboratorycultured cells, as well as those from Ekho Lake samples, was the frequent formation of elongated cells of up to $33 \mu \mathrm{m}$ in length (Table 2). Motility was observed in all strains except EL-219 ${ }^{\mathrm{T}}$. Electron microscopy revealed one to three subpolar flagella in strains EL-54 and EL-185 (Fig. 2).

\section{5 rRNA sequence determinations and phylogenetic analyses}

Partial 16S rRNA gene sequences of the four Ekho Lake isolates were determined by direct sequence analysis of PCR-amplified products. Based on a comparative analysis of a continuous stretch of approximately 800 bases, the isolates formed a distinct group, exhibiting $100 \% 16 \mathrm{~S}$ rRNA sequence similarity among each other. The almost complete 16S rRNA gene sequence ( $>1400$ bases) of strain EL-219 ${ }^{\mathrm{T}}$ as a representative was determined. For comparison, Ekho Lake strain EL-172 (a representative of another hybridization group) was also almost completely sequenced. Sequence searches of the EMBL database revealed the newly determined sequences were related to the $\alpha$-subclass of Proteobacteria (data not shown). Strain EL-219 ${ }^{\mathrm{T}}$ displayed the highest 16S rRNA sequence relatedness (approximately 92-94\%) with species of the genus Roseobacter (viz. R. algicola, $R$. litoralis and $R$. denitrificans), the latter was previously named Erythrobacter sp. Och 114 (37), Sagittula stellata (16), Sulfitobacter pontiacus (42), Octadecabacter antarcticus (17), a Sargasso sea isolate and the Ekho Lake strain EL-172. Other proteobacterial species examined showed significantly lower levels of relatedness. An unrooted tree depicting the phylogenetic relationships of the Ekho Lake strains and their close relatives is shown in Fig. 3. The results of treeing analyses confirmed that the Ekho Lake strain EL-219 ${ }^{\mathrm{T}}$ was phylogenetically most closely related to Roseobacter species and their close relatives. Strain EL-219 $9^{\mathrm{T}}$ formed a distinct subline within this grouping and clustered with another strain of Ekho Lake (EL-172). However, bootstrap resampling showed the relationship between Ekho Lake strains EL-219 ${ }^{\mathrm{T}}$ and EL-172 was supported in only $63 \%$ of trees. Furthermore, although bootstrap resampling showed that the bacterium from Ekho Lake was associated with the above-mentioned Roseobacter cluster (Fig. 3; bootstrap value $=100$ ), the unknown bacterium did not possess a particularly significant phylogenetic affinity with any species within this clade.

\section{Culture and growth characteristics}

Visible aerobic growth appeared after 3-5 d on medium PYGV $+25 \%$ (or $40 \%$ ) ASW and at $20{ }^{\circ} \mathrm{C}$. Colonies were circular, smooth, convex, $1-4 \mathrm{~mm}$ in diameter and brownish-yellow. On R2A agar + ASW, the colonies were brownish-red. Optimal growth occurred between 16 and $26^{\circ} \mathrm{C}$ and $\mathrm{pH}$ values of $6 \cdot 9-7.8$. The four isolates had an absolute requirement for $\mathrm{Na}^{+}$; the pairwise replacement of the other cations and anions (see Methods) did not influence normal growth yields. Likewise, $R$. denitrificans did not need $\mathrm{Cl}^{-}$or $\mathrm{SO}_{4}^{2-}$ under our growth conditions. The EL isolates had a requirement for thiamin, nicotinic acid and possibly biotin, but neither pantothenate nor vitamin $\mathrm{B}_{12}$ were required, as was also the case with $R$. denitrificans. Their osmotolerance ranged from $<10$ to $>150 \%$ ASW with an optimum between 10 and $40 \%$; however, strain EL-54 had an optimum between 40 and $70 \%$ ASW. The $\mathrm{NaCl}$ tolerance of EL-219 and EL-54 ranged from $<10$ to $100 \%$ with an optimum of $20-60 \% \mathrm{NaCl}$, and that of EL-165 and EL-185 from $<10-20$ to $40-60 \% \mathrm{NaCl}$ with an optimum at $20 \%$.

\section{Physiological and biochemical characteristics}

All four strains exhibited cytochrome oxidase, peroxidase and catalase activity. They did not produce acetoin or acids from glucose. They were susceptible to 


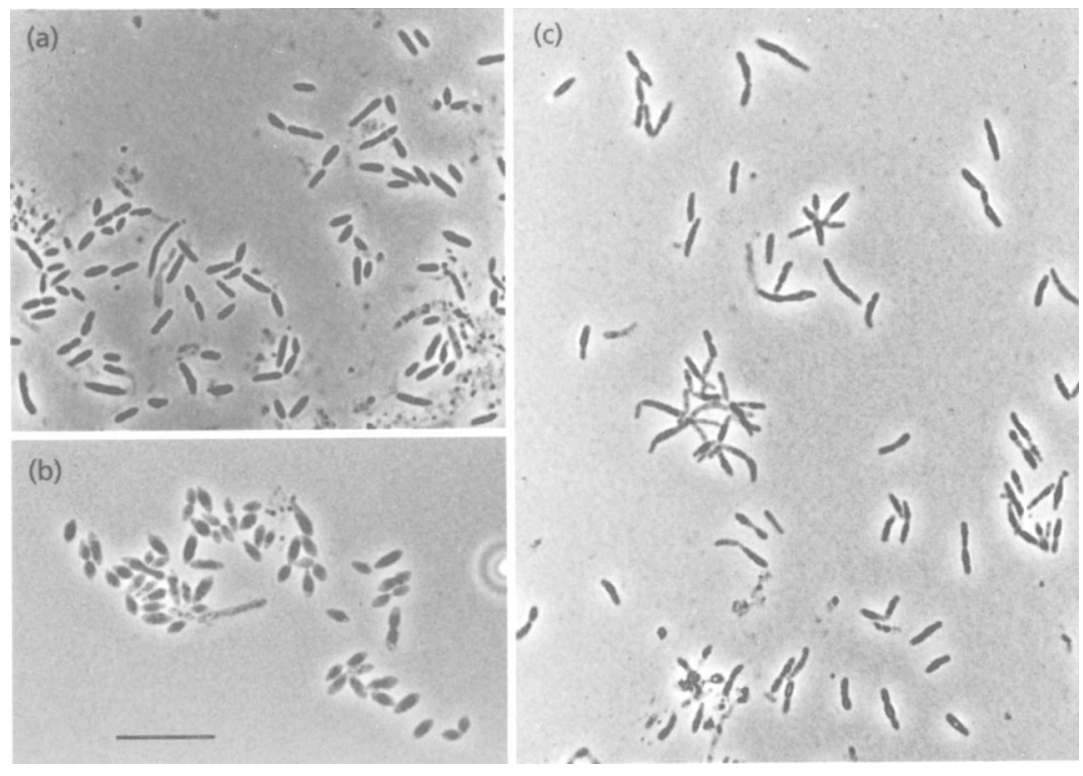

Fig. 1. Phase-contrast light micrographs of strains EL-219 $(a, b)$ and EL-165 (c) on agar-coated slides. Note differences in morphology and size of EL-219 cells due to either growth for $12 \mathrm{~d}$ on PYGV $+67 \%$ agar (a), or growth for $56 \mathrm{~d}$ on PYGV $+25 \% \mathrm{NaCl}$ agar (b). Cells of EL-165 (c) were cultivated for $29 \mathrm{~d}$ on PYGV $+67 \%$ ASW. Bar, $10 \mu \mathrm{m}$.

Table 2. Morphological characteristics of the EL strains, Sagittula stellata, R. algicola, R. denitrificans, R. litoralis and 'Marinosulfonomonas methylotropha'

\begin{tabular}{|c|c|c|c|c|c|c|c|}
\hline Organism: & Cell shape & Cell budding $\dagger$ & Storage granules ++ & Rosettes & Cell size (mean length) $(\mu \mathrm{m})$ & $\begin{array}{l}\text { Flagella; } \\
\text { motility } \$\end{array}$ & $\begin{array}{l}\text { Colony colour on } \\
\text { PYGV }\end{array}$ \\
\hline$E L-219^{r}$ & Rods, 12 poles pointed & + & PHBA & + & $0.81 .2 \times 2.5-10.9(5.5)$ & - & Brownish-yellow \\
\hline EL-54 & Rods, 1-2 poles pointed & + & PHBA & + & $0.81 .2 \times 2.0-11.0(3.8)$ & $1-3 ; s p$ & Brownish-yellow \\
\hline EL-165 & Long rods. 12 poles pointed & + & PHBA & + & $0.8-1.8 \times 2.5-33.6(7.7)$ & v & Brownish-yellow \\
\hline EL-185 & Rods. 12 poles pointed & + & PHBA & + & $0.8-1.5 \times 3.5-13.8(6.8)$ & $1-2 ; \mathrm{sp}$ & Brownish-yellow \\
\hline Sagittula sedind" & $\begin{array}{l}\text { Rods, I pole narrow: } \\
\text { holdfasts; fibrils }\end{array}$ & VD & PHBA & + & $0.9 \times 2.3$ & $+1-$ & Cream-coloured ${ }^{a}$ \\
\hline R. alyicolut & Ovoid rods & ND & PHBA & - & $0.8-1.5 \times 2 \cdot 0-3 \cdot 0$ & $1-2 ; s p$ & Brownish-beige" \\
\hline R. denitriticas: & Ovoid or rods & ND & ND & - & $0.60 .9 \times 1.2 .2 .0$ & $1-3 ; \mathrm{sp}$ & $\operatorname{Red}^{b}$ \\
\hline R. litoralis & Ovoid or rods & ND) & ND & - & $0.60 .9 \times 1.0-2.0$ & $1-3 ; \mathrm{sp}$ & $\operatorname{Red}^{\prime \prime}$ \\
\hline M. mothlytopha" & Rods & NI) & Polyphosphates & + & $0.5 \times 2.5$ & - & Semi-translucent ${ }^{c}$ \\
\hline
\end{tabular}

ND, Not determined.

* Data from reference: $a,(16) ; b,(27) ; c,(37) ; d,(22)$.

$\dagger$ Daughter cells substantially smaller than mother cells and often positioned at an angle.

$\leftarrow$ PHBA, poly- $\beta$-hydroxybutyrate.

$\S$ sp, subpolar to lateral; $v$, variable.

$\| a$, On Marine agar; $b$, present data supplement published diagnoses; $c$, on methanesulfonic acid/Phytagel $(1 \%$, w/v) medium.

$\checkmark$ Present data supplement published diagnoses.

chloramphenicol $(30 \mu \mathrm{g})$, penicillin $\mathrm{G}(10 \mathrm{U})$, streptomycin $(10 \mu \mathrm{g})$, tetracycline $(30 \mu \mathrm{g})$ and polymyxin B $(300 \mathrm{U})$. All strains reduced nitrate to nitrite. Nitrite was not reduced aerobically, and anaerobic reduction to $\mathrm{N}_{2}$ was variable. $\mathrm{H}_{2} \mathrm{~S}$ or indole was not produced. The following carbon sources were utilized in the presence of available nitrogen: succinate, butyrate, glutamate, acetate, pyruvate, malate, citrate and $\alpha$-Dglucose. Not utilized were methanol and methanesulfonic acid. In the absence of other nitrogen sources, glutamate was utilized as a carbon and nitrogen source. Without any added nitrogen source there was slight growth with acetate, butyrate, pyruvate, malate or succinate. The strains hydrolysed gelatin and DNA, but not Tween 80 or alginate. Other hydrolysis data and differences in the metabolism of carbon compounds as revealed with the BIOLOG system are shown in Table 3.

In the BIOLOG system, the isolates metabolized $\mathrm{N}$-acetyl-D-galactosamine, $\mathrm{N}$-acetylglucosamine, adonitol, D-arabitol, $i$-erythritol, D-fructose, L-fucose, D-galactose, gentiobiose, $\alpha$-D-glucose, $\alpha$-lactose, $\alpha$-Dlactose-lactulose, maltose, D-mannitol, D-mannose, D-melibiose, D-raffinose, L-rhamnose, D-sorbitol, sucrose, D-trehalose, turanose, acetic acid, citric acid, itaconic acid, propionic acid, glucuronamide, L-alanylglycine and uridine. They did not metabolize $\alpha$ - 


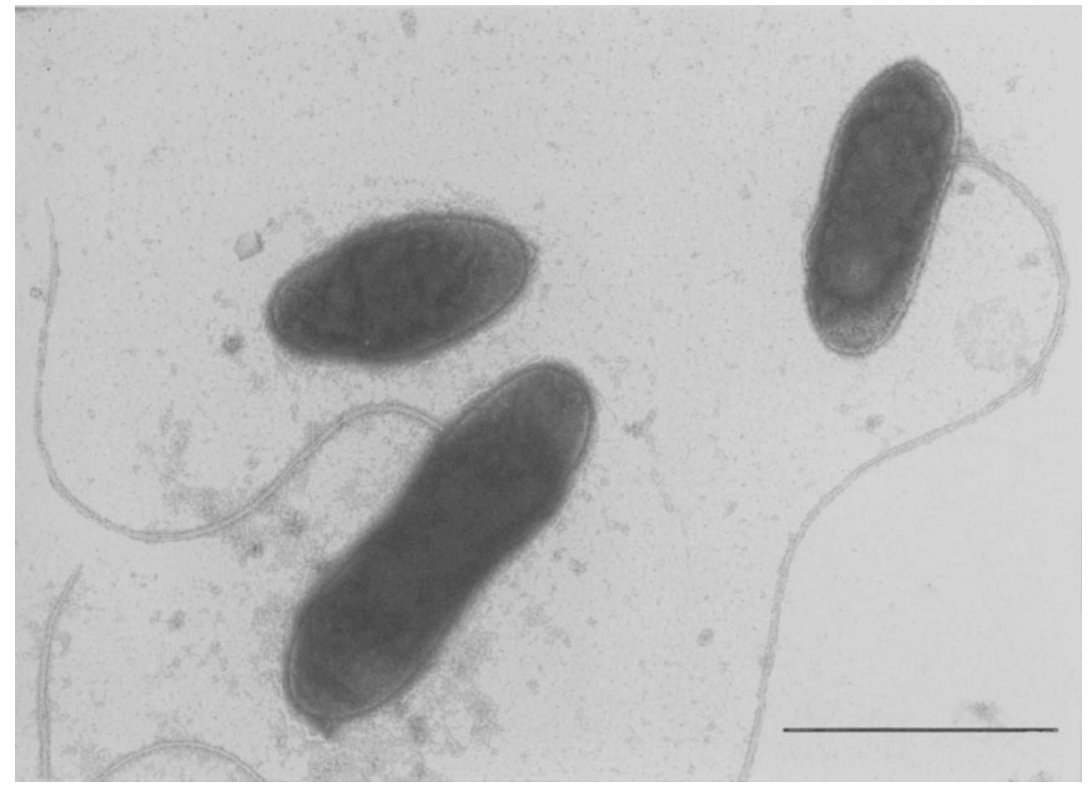

Fig. 2. Electron micrograph of phosphotungstic acid negatively stained cells and flagella of strain EL-54 after cultivation for $3 \mathrm{~d}$ in liquid medium PYGV $+75 \%$ ASW. The cell without a flagellum shows monopolar growth. Bar, $2 \mu \mathrm{m}$.

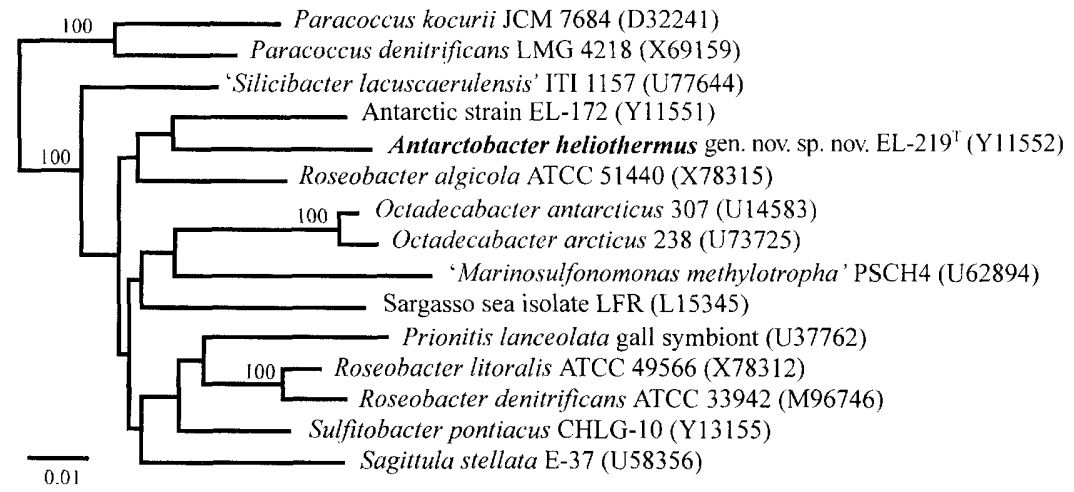

Fig. 3. Unrooted tree showing phylogenetic relationships of strain EL-219 ${ }^{\top}$ with EL-172 and closely related proteobacteria. The tree was constructed using the neighbour-joining method and $K_{\text {nuc }}$ values; it was based on a comparison of approximately 1400 nucleotides. Bootstrap values, expressed as a percentage of 500 replications, are given at branching points; only those above $90 \%$ are shown.

cyclodextrin, dextrin, glycogen, Tween $80, \beta$-methyl-Dglucoside, methyl pyruvate, cis-aconitic acid, monomethylsuccinate, formic acid, D-galactonic acid lactone, D-galacturonic acid, $\alpha$-hydroxybutyric acid, $\beta$-hydroxybutyric acid, $\gamma$-hydroxybutyric acid, $p$ hydroxyphenylacetic acid, $\alpha$-ketobutyric acid, $\alpha$-ketoglutaric acid, $\alpha$-ketovaleric acid, DL-lactic acid, sebacic acid, succinic acid, bromosuccinic acid, succinamic acid, D-alanine, L-aspartic acid, glycyl-L-glutamic acid, glycyl-L-aspartic acid, L-histidine, hydroxy-L-proline, L-leucine, L-ornithine, L-phenylalanine, L-proline, D-serine, L-pyroglutamic acid, DL-carnitine, $\gamma$-aminobutyric acid, urocanic acid, phenylethylamine, putrescine, 2-aminoethanol, glycerol, glucose 6-phosphate or DL- $\alpha$-glycerophosphate.

Strains EL-54 and EL-165 grew microaerobically, but they did not grow photolithoautotrophically under anaerobic conditions with $\mathrm{H}_{2} / \mathrm{CO}_{2}(80: 20)$ in the gas phase or photoorganotrophically. Bacteriochlorophyll $a$ was never found in cell suspensions or in methanolic extracts. Absorption spectra of methanolic extracts were very similar to those of $R$. algicola (27) grown on PYGV $+25 \%$ ASW. The $\mathrm{G}+\mathrm{C}$ content ranged from 62.3 to $62.8 \mathrm{~mol} \%$. Gene probes from EL-219 ${ }^{\mathrm{T}}$ hybridized with DNA from the other three Ekho Lake strains but not with DNA of $R$. denitrificans.

\section{Chemotaxonomic parameters}

The peptidoglycan of all four isolates contained $m$ diaminopimelic acid, and the peptidoglycan of strain EL-185 was of the directly cross-linked type A1 $\gamma$ (36). The ubiquinone of the four strains was Q-10. Polar lipid patterns and fatty acid compositions of the strains grown on PYGV + ASW are listed in Table 4 and compared to some other members of the $\alpha$-Proteobacteria. Their fatty acid profile was characterized by the predominance of $\mathrm{C}_{18: 1}$. 
Table 3. Differences in physiological properties of the EL strains

+ , Positive: -, negative; $\mathrm{v}$, variable; $\mathrm{w}$, weak; ND, not determined.

\begin{tabular}{|lcccc|}
\hline Character & EL-219 & EL-54 & EL-165 & EL-185 \\
\hline BIOLOG data & & & & \\
Tween 40 & - & + & - & - \\
L-Arabinose & - & + & - & $\mathrm{V}$ \\
Cellobiose & - & + & - & - \\
m-Inositol & - & + & - & - \\
Psicose & - & - & - & + \\
Xylitol & $\mathrm{V}$ & + & $\mathrm{V}$ & $\mathrm{V}$ \\
D-Gluconic acid & - & + & - & - \\
D-Glucosaminic acid & - & + & $\mathrm{V}$ & - \\
D-Glucuronic acid & - & + & - & - \\
Malonic acid & - & + & - & - \\
Quinic acid & - & $\mathrm{V}$ & - & - \\
D-Saccharic acid & - & + & - & $\mathrm{V}$ \\
Alaninamide & - & + & - & $\mathrm{V}$ \\
L-Alanine & - & $\mathrm{V}$ & - & $\mathrm{V}$ \\
L-Asparagine & - & + & - & - \\
L-Glutamic acid & - & $\mathrm{V}$ & - & - \\
L-Serine & - & $\mathrm{V}$ & - & - \\
Inosine & - & + & + & - \\
Thymidine & - & $\mathrm{V}$ & - & $\mathrm{V}$ \\
2,3-Butanediol & - & $\mathrm{V}$ & - & - \\
Glucose 1-phosphate & - & $\mathrm{V}$ & - & - \\
Hydrolysis of: & & & & \\
Starch & - & - & + & $\mathrm{W}$ \\
$\beta$-D-Glucoside & - & $\mathrm{ND}$ & - & - \\
\hline
\end{tabular}

\section{DISCUSSION}

The three very different enrichment procedures used for Ekho Lake samples yielded four nearly identical bacterial isolates, although these came from 5-16 m depth. Apart from the salinity $(60-76 \%)$, the original samples were fairly similar, and thus it may be possible that the isolates were widely distributed in the upper layers of the lake. DNA of all four isolates hybridized with gene probes of strain EL-219 $9^{\mathrm{T}}$ (75\% stringency), and sequencing of $16 \mathrm{~S}$ rDNA confirmed the isolates were genealogically homogeneous and members of a distinct taxon within the $\alpha-3$-subclass of the Proteobacteria. The four isolates displayed very similar morphologies (Table 2). Strain EL-219 $9^{\mathrm{T}}$ did not exhibit directed motility but rather a tumbling and twitching of daughter cells. There were only minor differences in biochemical and physiological activities such as in the hydrolysis of starch or in the metabolism of carbon compounds as revealed by the BIOLOG system (Table $3)$. The strains were also identical in the battery of chemotaxonomic tests employed: they all contained ubiquinones as the sole respiratory quinones, indicating that the organisms were members of the $\alpha-, \beta$ - or $\gamma$-subclasses of the Proteobacteria. Generally, Q-10 is the major respiratory quinone only in members of the $\alpha$-subclass of the Proteobacteria, although some organisms, such as Legionella spp. in the $\gamma$-subclass of Proteobacteria, also produce Q-10, which is accompanied by significant quantities of other, long-chain homologues. The fatty acid pattern of the EL strains was dominated by the presence of a $\mathrm{C}_{18: 1}$ fatty acid. This predominance, in combination with the presence of Q-10, is again typical of members of the $\alpha$-subclass of Proteobacteria. The only indication of the presence of non-ester-linked fatty acids (potentially amidelinked fatty acids) was found among the 3-hydroxy fatty acids. The polar lipid composition of all strains indicated that the organisms contained phospholipids as the major polar lipids. Taken together, the sum of respiratory lipoquinones, fatty acids and polar lipid data indicated that the strains examined belonged to a group of organisms (at the genus or family rank) within the $\alpha$-subclass of the Proteobacteria.

Comparative 16S rDNA gene sequencing showed also that the unknown bacteria from Ekho Lake, as exemplified by EL-219 , were members of the $\alpha$ subclass of Proteobacteria and were specifically associated with the Roseobacter supercluster of organisms, which included 'Marinosulfonomonas' (22), Prionitis lanceolata gall symbiont, Octadecabacter, Roseobacter, Sagittula, Sulfitobacter and an unknown Sargasso sea isolate. This cluster was supported by a bootstrap value of $100 \%$. Sequence divergence values of $>5 \%$ showed that the unknown bacteria were genetically distinct from all currently recognized members of the Proteobacteria. Furthermore, bootstrap resampling showed that EL-219 $9^{\mathrm{T}}$ from Ekho Lake did not possess a particularly significant phylogenetic affinity with any individual species within the above-mentioned genera (Fig. 3). The association between Ekho Lake strains EL-219 $19^{\mathrm{T}}$ and EL-172 was recovered in only $63 \%$ of trees (500 replicates). It is evident from the treeing analyses that the genus Roseobacter as currently recognized is not monophyletic, with several taxa (e.g. Prionitis lanceolata gall symbiont, Sulfitobacter) interdispersed with species of this genus. Based on sequence divergence values combined with tree topology considerations, it is evident that the Ekho Lake strain EL$219^{\mathrm{T}}$ merits a similar taxonomic rank (i.e. genus) as that of Sagittula, Prionitis lanceolata gall symbiont, Sulfitobacter and Octadecabacter. In view of the phylogenetic separation of the unknown bacteria and their phenotypic distinctiveness (Table 5), we conclude that the four Ekho Lake isolates are representatives of a new and distinct taxon for which we formally propose the name Antarctobacter heliothermus gen. nov., sp. nov.

\section{Description of Antarctobacter gen. nov.}

Antarctobacter [Ant.arc.to.bac'ter. Antarctica M.L. name of the South Pole continent, derived from Gr. pref. anti against (on the other side), Gr. adj. arcticos northern; Gr. n. baktron a rod or staff; M.L. masc. n. 
M. Labrenz and others

Table 4. Chemotaxonomic characteristics of the EL strains, Sagittula stellata, $R$. algicola, $R$. denitrificans, $R$. litoralis, $O$. arcticus and 0 . antarcticus

For the FAME composition data, values less than $1 \%$ and unidentified FAMEs are not shown. All polar lipid data are from the present study; strains were cultivated on PYGV + ASW. ND, Not determined.

\begin{tabular}{|c|c|c|c|c|c|c|c|c|c|c|}
\hline Characteristic & $\begin{array}{l}\text { EL- } \\
219^{\mathrm{T}}\end{array}$ & $\begin{array}{c}\text { EL- } \\
54\end{array}$ & $\begin{array}{l}\text { EL- } \\
165\end{array}$ & $\begin{array}{l}\text { EL- } \\
185\end{array}$ & $\begin{array}{c}S . \\
\text { stellata }\end{array}$ & $\begin{array}{c}R . \\
\text { algicola } \dagger \ddagger\end{array}$ & $\begin{array}{c}R . \\
\text { denitrificans }\end{array}$ & $\begin{array}{c}\boldsymbol{R} . \\
\text { litoralis } \dagger \S\end{array}$ & $\begin{array}{c}O . \\
\text { arcticus } \|\end{array}$ & $\begin{array}{c}o . \\
\text { antarcticus }\end{array}$ \\
\hline \multicolumn{11}{|l|}{ FAME composition (\%) } \\
\hline $\mathrm{C}_{10.0} 3-\mathrm{OH}$ & & & & & & & $4 \cdot 2$ & 1.9 & $4 \cdot 0$ & $2 \cdot 0$ \\
\hline $\mathrm{C}_{12: 1} 3-\mathrm{OH}$ & $3 \cdot 1$ & $3 \cdot 1$ & $3 \cdot 0$ & $3 \cdot 1$ & $3 \cdot 6$ & & & & & \\
\hline $\mathrm{C}_{14: 0} 2-\mathrm{OH}$ & & & & & & & & 3.9 & & \\
\hline$C_{16: 1}$ & 0.8 & $1 \cdot 1$ & $0 \cdot 8$ & 0.6 & & & $1 \cdot 4$ & & $8 \cdot 0$ & $12 \cdot 0$ \\
\hline$C_{16: 0}^{10.1}$ & $2 \cdot 5$ & $2 \cdot 7$ & $2 \cdot 5$ & $2 \cdot 3$ & 8.6 & 1.6 & $1 \cdot 6$ & $1 \cdot 1$ & $6 \cdot 0$ & $6 \cdot 0$ \\
\hline$C_{18: 2}$ & & & & & & 1.6 & $7 \cdot 1$ & $1 \cdot 4$ & & \\
\hline $\mathrm{C}_{18: 1}$ & $83 \cdot 2$ & $81 \cdot 9$ & $81 \cdot 4$ & $84 \cdot 0$ & 9 & 91.5 & $84 \cdot 6$ & $88 \cdot 8$ & $75 \cdot 0$ & $77 \cdot 0$ \\
\hline$C_{18: 0}$ & $1 \cdot 0$ & $0 \cdot 7$ & $1 \cdot 1$ & $1 \cdot 4$ & $6 \cdot 8$ & $2 \cdot 2$ & $1 \cdot 2$ & $1 \cdot 3$ & & \\
\hline $\mathrm{C}_{19: 0}^{10.0} \mathrm{cyc}$ & $2 \cdot 4$ & 2.5 & $2 \cdot 7$ & 1.9 & 1.8 & & & & & \\
\hline \multicolumn{11}{|l|}{ Polar lipids } \\
\hline Phosphatidylglycerol & + & + & + & + & ND & + & + & + & ND & $\mathrm{ND}$ \\
\hline Phosphatidylcholine & + & + & + & + & $\mathrm{ND}$ & + & + & - & $\mathrm{ND}$ & ND \\
\hline Diphosphatidylglycerol & - & - & - & - & $\mathrm{ND}$ & + & + & + & $\mathrm{ND}$ & $\mathrm{ND}$ \\
\hline Phosphatidylethanolamine & - & - & - & - & ND & + & - & - & ND & ND \\
\hline Unknown aminolipid & + & + & + & + & ND & + & + & + & $\mathrm{ND}$ & $\mathrm{ND}$ \\
\hline Unknown phospholipid(s) & + & + & + & + & $\mathrm{ND}$ & - & + & + & $\mathrm{ND}$ & $\mathrm{ND}$ \\
\hline
\end{tabular}

* Data from reference (16)

$\dagger$ Grown on Marine broth.

Data from the present study.

$\S$ Present data supplement published diagnoses.

|| Data from reference (17)

- Major fatty acid, but not quantified.

Table 5. Comparison of isolate EL-219 ${ }^{\top}$ and the other related strains with Sagittula stellata (16), $R$. algicola (27), $R$. denitrificans (37), R. litoralis (37), Sulfitobacter pontiacus (42), O. arcticus (17), O. antarcticus (17) and 'Marinosulfonomonas methylotropha' (22)

+ , Positive; -, negative; ND, not determined; w, weak reaction.

\begin{tabular}{|c|c|c|c|c|c|c|c|c|c|}
\hline Characteristic & $E L-219^{\mathrm{r}}$ & S. stellata & R. algicola & R. denitrificans & R. litoralis & S. pontiacus & O. arcticus & O. antarcticus & 'M. methylotropha' \\
\hline Cell shape & Rods & Rods & Ovoid & Ovoid & Ovoid & Rods & Rods & Rods & Rods \\
\hline Rosettes formed & + & + & - & - & - & + & - & - & + \\
\hline Colony colour & Brown-yellow & Cream & Brown-beige & Pink & Pink & Colourless & White & White & Translucent \\
\hline Gas vesicles & - & - & - & - & - & - & + & + & - \\
\hline Motility & $+1-$ & $+^{*}$ & + & + & + & + & - & - & - \\
\hline Maximum length $(\mu \mathrm{m})$ & $10 \cdot 9-33 \cdot 6$ & $2 \cdot 3$ & $2-3$ & 2 & 2 & $2-5$ & $4 \cdot 4$ & $4 \cdot 8$ & $2 \cdot 5$ \\
\hline Minimum temp $\left({ }^{\circ} \mathrm{C}\right)$ & $3-8 \cdot 5$ & $<4$ & 10 & $<2$ & 2 & 4 & $<4$ & $<4$ & 20 \\
\hline Maximum temp. $\left({ }^{\circ} \mathrm{C}\right)$ & $33 \cdot 5-43 \cdot 5$ & $>41$ & $>37$ & $>30$ & $>30$ & 35 & $>15$ & 1015 & 37 \\
\hline Nicotinic acid requirement & + & - & - & + & + & ND & + & ND & ND \\
\hline Biotin requirement & $w$ & - & + & + & + & ND & - & ND & ND \\
\hline Dissimilatory $\mathrm{NO}_{3}^{-}$reduction & + & - & - & + & - & ND & - & - & ND \\
\hline Assimilatory $\mathrm{NO}_{3}^{-}$reduction & + & - & - & $+t^{+}$ & ND & $\mathrm{ND}$ & - & ND & + \\
\hline Carbon source: methanol & - & + & - & - & - & - & - & - & + \\
\hline Carbon source: butyrate & + & + & $-\ddagger$ & - & - & + & - & - & ND \\
\hline Cellulase activity & - & + & $\mathrm{ND}^{+}$ & ND & ND & $\mathrm{ND}$ & ND & ND & ND \\
\hline Gelatine hydrolysis & + & - & + & + & + & - & - & - & ND \\
\hline Bacteriochlorophyll $a$ & - & - & - & + & + & - & - & - & - \\
\hline $\mathrm{G}+\mathrm{C}$ content $(\mathrm{mol} \%)$ & $62 \cdot 3-62 \cdot 8$ & 65 & $64 \uparrow$ & $59 \cdot 6$ & $56 \cdot 3-58 \cdot 1$ & $62 \cdot 1$ & 57 & 56 & 57 \\
\hline
\end{tabular}

* Motility was assumed since flagella were found in suspension, but motile cells were not seen.

$\dagger$ Data from the present study.

$¥$ Positive in the present study. 
bacter; M.L. masc. n. Antarctobacter a rod-shaped bacterium from Antarctica].

Gram-negative rods, multiplying by monopolar growth, i.e. by a budding process. Daughter cells may be motile. Cell sizes vary due to age and growth conditions: $0.8-1.2 \times 2.0-33.6 \mu \mathrm{m}$. The cells may contain poly- $\beta$-hydroxybutyrate; rosettes are formed. Do not form spores. Colonies smooth, convex and brownish to yellowish on medium PYGV with ASW, or brownish-red on medium R2A with ASW. The temperature range for growth is $<3-43.5{ }^{\circ} \mathrm{C}$. The cells have an absolute requirement for $\mathrm{Na}^{+}$, and grow in the range of $<10$ to $<100 \% \mathrm{NaCl}$. They grow between $<10$ and $>150 \%$ ASW. The $\mathrm{pH}$ tolerance range is $5 \cdot 3->9$. Strictly aerobic, non-fermentative heterotrophs. The cells exhibit cytochrome oxidase, peroxidase and catalase activities. No growth on glucose anaerobically in the absence of nitrate. They do not grow photoautotrophically with $\mathrm{H}_{2} / \mathrm{CO}_{2}(80: 20)$ or photoorganotrophically with acetate or glutamate; they do not contain bacteriochlorophyll $a$. The peptidoglycan contains $m$-diaminopimelic acid and is of the directly cross-linked type Al $\gamma$. The respiratory quinone is Q-10. The following polar lipids are present: phosphatidylglycerol, phosphatidylcholine as well as unknown phospholipids and an aminolipid. The dominant fatty acid is $\mathrm{C}_{18: 1}$; another characteristic fatty acid is $\mathrm{C}_{12: 1} 3-\mathrm{OH}$. The $\mathrm{G}+\mathrm{C}$ content is $62 \cdot 3$ $62.8 \mathrm{~mol}^{\%} \%$. Origin: water samples from Ekho Lake, Antarctica (Vestfold Hills). The type species for the genus is Antarctobacter heliothermus.

\section{Description of Antarctobacter heliothermus sp. nov.}

Antarctobacter heliothermus (he.li.o.ther'mus. Gr. n. helios Sun; Gr. adj. thermos hot; M.L. masc. adj. heliothernius heated by the Sun, referring to the heliothermal waters of Ekho Lake, from where the species was isolated).

Rods with a mean length of 3.8-7.7 $\mu \mathrm{m}$. One or both cell poles nearly pointed. Daughter cells may be motile with one to three subpolar flagella. Optimal growth occurs at $16-26{ }^{\circ} \mathrm{C}$ with salt concentrations of $2060 \%$ $\mathrm{NaCl}$ or $10-70 \%$ ASW. The optimum $\mathrm{pH}$ is $6 \cdot 9-7 \cdot 8$. Requires thiamin and nicotinic acid but not pantothenate or vitamin $\mathrm{B}_{12}$; they are stimulated by biotin. Nitrate is reduced to nitrite and dissimilatory reduction of nitrite is variable. $\mathrm{H}_{2} \mathrm{~S}$ and indole are not produced. Hydrolyses gelatin and DNA, but not Tween 80 and alginate. Hydrolysis of starch is variable. Cellulase activity was not detected. Growth occurs on acetate, pyruvate, malate, citrate, succinate, butyrate, glutamate or $\alpha$-D-glucose. Glutamate is used with and without an additional source of combined nitrogen. In the absence of any added nitrogen compounds, the cells grow slightly on acetate, pyruvate, succinate, malate or butyrate. Methanol or methanesulfonic acid are not used. Susceptible to chloramphenicol, penicillin G, streptomycin, tetracycline and polymyxin B. Further description as for the genus. The type strain
EL-219 ${ }^{\mathrm{T}}$ was deposited in the Deutsche Sammlung von Mikroorganismen und Zellkulturen (DSM 11445 $)$. Additional isolates are EL-165 (DSM 11440), EL-54 and EL-185.

\section{ACKNOWLEDGEMENTS}

Skilful technical assistance of B. Hoffmann, M. Beese and R. Emcke is gratefully acknowledged; J. Siebert assisted with the Antarctic field work and H. Völker (Kiel) helped with electron microscopy. P. Schumann (DSMZ, Jena) has helped with the identification of fatty acids and N. Weiss (DSMZ Braunschweig) with cell wall analyses. We wish especially to express our gratitude to the Australian Antarctic Division (Kingston, Tasmania) for supporting two eventful visits to the Vestfold Hills (Antarctica), and especially to H. R. Burton and T. A. McMeekin (Hobart, Tasmania) for their practical help and hospitality. We are grateful to the Deutsche Forschungsgemeinschaft (grants Hi 68/16-3, Hi 68/19-3 and Hi 68/25-1/2) and the European Union (CT 930194 and CT 93-0119) for support.

\section{REFERENCES}

1. Bradford, M. M. (1976). A rapid and sensitive method for the quantitation of microgram quantities of protein utilizing the principle of protein-dye binding. Anal Biochem 72, 248-254.

2. Cohen-Bazire, G., Sistrom, W. R. \& Stanier, R. Y. (1957). Kinetic studies of pigment synthesis by non-sulfur purple bacteria. J Cell Physiol 49, 25-68.

3. Devereux, J., Haeberli, P. \& Smithies, O. (1984). A comprehensive set of sequence analysis programs for the VAX. Nucleic Acids Res 12, 387-395.

4. Dobson, S. J., James, S. R., Franzmann, P. D. \& McMeekin, T. A. (1991). A numerical taxonomy study of some pigmented bacteria isolated from Organic Lake, an antarctic hypersaline lake. Arch Microbiol 156, 56-61.

5. Dobson, S. J., McMeekin, T. A. \& Franzmann, P. D. (1993). Direct sequencing of the polymerase chain reaction-amplified 16S rRNA gene of Flavobacterium gondwanense sp. nov. and Flavobacterium salegens sp. nov., two new species from a hypersaline antarctic lake. Int $J$ Syst Bacteriol 43, $77-83$.

6. Dobson, S. J., McMeekin, T. A. \& Franzmann, P. D. (1993). Phylogenetic relationships between some members of the genera Deleya, Halomonas, and Halovibrio. Int $J$ Syst Bacteriol 43, 665-673.

7. Drews, G. (1974). Mikrobiologisches Praktikum, 2nd edn. Berlin: Springer.

8. Felsenstein, J. (1989). PHYLIP - phylogeny inference package (version 3.2). Cladistics 5, 164-166.

9. Ferris, J. M., Gibson, J. A. E. \& Burton, H. R. (1991). Evidence of density currents with the potential to promote meromixis in ice-covered saline lakes. Palaeogeogr Palaeoclimatol Palaeoecol 84, 99-107.

10. Franzmann, P. D., Burton, H. R. \& McMeekin, T. A. (1987). Halomonas subglaciescola, a new species of halotolerant bacteria isolated from Antarctica. Int J Syst Bacteriol 37, 27-34.

11. Franzmann, P. D. \& Dobson, S. J. (1992). Cell wall-less, freeliving spirochaetes in Antarctica. FEMS Microbiol Lett 97 , 289-292. 
12. Franzmann, P. D., Höpfl, P., Ness, N. \& Tindall, B. J. (1991). Psychrotrophic, lactic acid-producing bacteria from anoxic waters in Ace Lake, Antarctica; Carnobacterium funditum sp. nov. and Carnobacterium alterfunditum sp. nov. Arch Microbiol 156, 255-262.

13. Franzmann, P. D. \& Rohde, M. (1991). An obligately anaerobic, coiled bacterium from Ace Lake, Antarctica. J Gen Microbiol 137, 2191-2196.

14. Franzmann, P. D., Springer, N., Ludwig, W., Conway de Macario, E. \& Rohde, E. (1992). A methanogenic archaeon from Ace Lake, Antarctica: Methanococcoides burtonii sp. nov. Syst Appl Microbiol 15, 573-581

15. Franzmann, P. D., Stackebrandt, E., Sanderson, K., Volkman, J. K., Cameron, D. E., Stevenson, P. L., McMeekin, T. A. \& Burton, H. R. (1988). Halobacterium lacusprofundi sp. nov., a halophilic bacterium isolated from Deep Lake, Antarctica. Syst Appl Microbiol 11, 20-27.

16. Gonzalez, J. M., Mayer, F., Moran, M. A., Hodson, R. E. \& Whitman, W. B. (1997). Sagittula stellata gen. nov., sp. nov., a lignin-transforming bacterium from a coastal environment. Int J Syst Bacteriol 47, 773-780.

17. Gosink, J. J., Herwig, R.P. \& Staley, J. T. (1997). Octadecabacter arcticus gen. nov., sp. nov., and $O$. antarcticus, sp. nov., nonpigmented, psychrophilic gas vacuolate bacteria from polar sea ice and water. Syst Appl Microbiol 20, $356-365$.

18. Hirsch, P. (1974). Budding bacteria. Annu Rev Microbiol 28, 391- 444.

19. Hirsch, P. (1980). Distribution and pure culture studies of morphologically distinct Solar Lake microorganisms. In Hypersaline Brines and Evaporitic Environments, pp. 41-60. Edited by A. Nissenbaum. Amsterdam: Elsevier.

20. Hirsch, P. \& Hensiek, S. (1998). Tetraselmis antarctica $\mathrm{sp.}$ nov., a praseophyte from hypersaline, heliothermal and meromictic Ekho Lake (Vestfold Hills, East Antarctica) (unpublished)

21. Hirsch, P. \& Hoffmann, B. (1989). Dichotomicrobium thermohalophilum gen. nov., sp. nov., budding prosthecate bacteria from the Solar Lake (Sinai) and some related strains. Syst Appl Microbiol 11, 291-301.

22. Holmes, A. J., Kelly, D. P., Baker, S. C., Thompson, A. S. Marco, P. D., Kenna, E. M. \& Murrell, J. C. (1997). Methylosulfonomonas methylovora gen. nov., sp. nov., and Marinosulfonomonas methylotropha gen. nov., sp. nov.: novel methylotrophs able to grow on methanesulfonic acid. Arch Microbiol 167, 46-53.

23. Hudson, R. A., Thompson, D. E. \& Collins, M. D. (1993). Genetic interrelationships of saccharolytic Clostridium botulinum types $\mathrm{B}, \mathrm{E}$ and $\mathrm{F}$ and related clostridia by smallsubunit rRNA gene sequences. FEMS Microbiol Lett 108, 103-110.

24. James, S. R., Burton, H. R., McMeekin, T. A. \& Mancuso, C. A. (1994). Seasonal abundance of Halomonas meridiana, Halomonas subglaciescola, Flavobacterium gondwanense and Flavobacterium salegens in four antarctic lakes. Antarct Sci 6, 325-332.

25. Jukes, T. H. \& Cantor, C. R. (1969). Evolution of protein molecules. In Mammalian Protein Metabolism, pp. 21-132. Edited by H. N. Munro. New York: Academic Press.

26. Kreisel, H. \& Schauer, F. (1987). Methoden des mykologischen Laboratoriums. Stuttgart: Gustav Fischer.
27. Lafay, B., Ruimy, R., Rausch de Traubenberg, C., Breittmayer, V., Gauthier, M. J. \& Christen, R. (1995). Roseobacter algicola sp. nov., a new marine bacterium isolated from the phycosphere of the toxin-producing dinoflagellate Prorocentrum lima. Int J Syst Bacteriol 45, 290-296.

28. Lyman, J. \& Fleming, R. H. (1940). Composition of sea water. $J$ Mar Res (Sears Foundation) 3, 134-146.

29. Mesbah, M., Premachandran, U. \& Whitman, W. B. (1989). Precise measurement of the $\mathrm{G}+\mathrm{C}$ content of deoxyribonucleic acid by high-performance liquid chromatography. Int J Syst Bacteriol 39, 159-167.

30. Pearson, W. R. \& Lipman, D. J. (1988). Improved tools for biological sequence comparison. Proc Natl Acad Sci USA 85, 2444-2448.

31. Pfennig, N. \& Wagener, S. (1986). An improved method of preparing wet mounts for photomicrographs of microorganisms. J Microbiol Methods 4, 303-306.

32. Rhuland, L. E., Work, E., Denman, R. F. \& Hoare, D. S. (1955). The behavior of the isomers of $\alpha, \varepsilon$-diaminopimelic acid on paper chromatograms. $J$ Am Chem Soc 77, 4844 4846.

33. Saitou, N. \& Nei, M. (1987). The neighbor-joining method: a new method for reconstructing phylogenetic trees. Mol Biol Evol 4, 406-425.

34. Sambrook, J., Fritsch, E. F. \& Maniatis, T. (1989). Molecular Cloning: a Laboratory Manual, 2nd edn. Cold Spring Harbor, NY: Cold Spring Harbor Laboratory.

35. Sasser, M. (1990). Identification of bacteria by gas chromatography of cellular fatty acids. USFCC Newsl 20, 1-6.

36. Schleifer, K. H. \& Kandler, O. (1972). Peptidoglycan types of bacterial cell walls and their taxonomic implications. Bacteriol Rev 36, 407-477.

37. Shiba, T. (1991). Roseobacter litoralis gen. nov., sp. nov., and Roseobacter denitrificans sp. nov., aerobic pink-pigmented bacteria which contain bacteriochlorophyll a. Syst Appl Microbiol 14, 140-145.

38. Shiba, T. \& Simidu, U. (1982). Erythrobacter longus gen. nov., sp. nov., an aerobic bacterium which contains bacteriochlorophyll a. Int J Syst Bacteriol 32, 211-217.

39. Skerman, V. B. D. (1967). A Guide to the Identification of the Genera of Bacteria, 2nd edn. Baltimore: Williams \& Wilkins.

40. Smibert, R. M. \& Krieg, N. R. (1994). Phenotypic characterization. In Methods for General and Molecular Bacteriology, pp. 607-654. Edited by P. Gerhardt, R. G. E. Murray, W. A. Wood \& N. R. Krieg. Washington, DC: American Society for Microbiology.

41. Staley, J. T. (1968). Prosthecomicrobium and Ancalomicrobium, new prosthecate fresh water bacteria. $J$ Bacteriol 95, 1921-1944.

42. Sorokin, D. Y. (1995). Sulfitobacter pontiacus gen. nov., sp. nov. - a new heterotrophic bacterium from the Black Sea, specialized on sulfite oxidation. Microbiologiya 64, 295-305.

43. Tindall, B. J. (1990). A comparative study of the lipid composition of Halobacterium saccharovorum from various sources. Syst Appl Microbiol 13, 128-130.

44. Tindall, B. J. (1990). Lipid composition of Halobacterium lacusprofundi. FEMS Microbiol Lett 66, 199--202.

45. Van Ert, M. \& Staley, J. T. (1971). Gas-vacuolated strains of Microcyclus aquaticus. J Bacteriol 108, 236-240. 